\title{
Genistein inhibits estradiol- and environmental endocrine disruptor-induced growth effects on neuroblastoma cells in vitro
}

\author{
JICUI ZHENG ${ }^{1 *}, \mathrm{HUI} \mathrm{LI}^{1,2^{*}}$, HAITAO ZHU $^{1}$, XIANMIN XIAO $^{1}$ and YANGYANG MA ${ }^{1}$ \\ ${ }^{1}$ Department of Pediatric Surgery, Children's Hospital, Fudan University, Shanghai 201102; \\ ${ }^{2}$ Department of Pediatric Surgery, Children's Hospital, Jiao Tong University, Shanghai 200040, P.R. China
}

Received May 9, 2012; Accepted September 14, 2012

DOI: $10.3892 / \mathrm{ol} .2013 .1236$

\begin{abstract}
The aim of this study was to examine the effect of genistein on human neuroblastoma cell proliferation induced by two common environmental endocrine disruptors, bisphenol A (BPA) and Di-2-ethylhexyl phthalate (DEHP), and to investigate its underlying mechanism. SK-N-SH human neuroblastoma cells were treated with $\mathrm{E}_{2}(1 \mathrm{ng} / \mathrm{ml}), \mathrm{BPA}(2 \mu \mathrm{g}$ / $\mathrm{ml})$ or DEHP $(100 \mu \mathrm{M})$, with or without genistein $(12.5 \mu \mathrm{M})$ in vitro. The number of viable cells was detected with an absorbance reader after $0,24,48$ or $72 \mathrm{~h}$ treatment. The percentage of cells in different phases, and expression of Akt and its phosphorylation levels were also assessed by flow cytometry and western blot analysis at $72 \mathrm{~h}$, respectively. The BPA and DEHP groups had a $30 \%$ higher number of viable cells compared to the non-treated group at $48 \mathrm{~h}(\mathrm{P}<0.001)$. However, the cell numbers did not increase significantly in the groups with additional treatment with genistein ( $\mathrm{P}>0.05$ vs. control) and the same trend was observed at $72 \mathrm{~h}$. The expression of phospho-Akt protein was increased in the groups treated with BPA or DEHP compared to the control group at $72 \mathrm{~h}(\mathrm{P}<0.05)$, while no significant elevation in the expression of phosphoAkt was observed $(\mathrm{P}>0.05)$ in genistein-treated groups. Cells were arrested at the $G_{2} / M$ phase by genistein. Similar effects were observed in the $\mathrm{E}_{2}$ group with or without genistein treatment. Akt protein expression had no significant change among all the groups $(\mathrm{P}>0.05)$. In conclusion, estradiol- or environmental endocrine disruptor-induced proliferation of human neuroblastoma cells is effectively abolished by genistein, likely in a cell cycle- and Akt pathway-dependent manner.
\end{abstract}

Correspondence to: Dr Xianmin Xiao, Department of Pediatric Surgery, Children's Hospital, Fudan University, 399 Wanyuan Road, Shanghai 201102, P.R. China

E-mail: zhubindoctor@126.com

*Contributed equally

Key words: neuroblastoma, environmental endocrine disruptors, genistein, Akt

\section{Introduction}

Neuroblastoma is a common extracranial childhood solid tumor $(1,2)$. The majority of neuroblastomas are highly metastastic with poor clinical outcome despite the application of intensive multimodal therapy (3). However, its oncogenesis is still poorly understood. Our previous studies showed that environmental endocrine disruptors (EEDs) may be one of the most important causes of the carcinogenesis of neuroblastoma $(4,5)$. A recent multicenter case-control survey also showed that paternal exposure to hydrocarbons was associated with an increased incidence of neuroblastoma in children (6). Therefore, specific antagonists blocking EED-dependent adverse effects may potentially protect against neuroblastoma occurrence and become a new option for the treatment of patients with neuroblastoma in the clinical practice.

Isoflavones are natural compounds that commonly exist in soy-based foods. They display a variety of biological activities including suppression of activity of several enzymes that regulate cell proliferation (7), prevention of cell-cycle progression (8) and inhibition of tumor growth (7). Genistein 4',5,7-trihydroxyisoflavone, also known as genistein, is one of the major soy isoflavones. Genistein is considered to be a promising therapeutic candidate for various cancers (9-11).

However, the effects of genistein on neuroblastoma cell growth, especially those induced by EED and its molecular mechanisms, are rarely reported. In this study, we used SK-N-SH human neuroblastoma cells as a cell model, and investigated the effect of genistein on the bisphenol A (BPA)and Di-2-ethylhexl phthalate (DEHP)-induced proliferation of human neuroblastoma in vitro.

\section{Materials and methods}

Cell line, reagents and antibodies. SK-N-SH, a human neuroblastoma cell line, was purchased from Shanghai Institute for Biological Sciences, Chinese Academy of Sciences (Shanghai, China). Roswell Park Memorial Institute-1640 (RPMI-1640) medium, phenol red-free RPMI-1640 medium and fetal bovine serum (FBS) were obtained from Gibco (Invitrogen, Carlsbad, CA, USA). 17 $\beta$-estradiol $\left(\mathrm{E}_{2}\right)$, genistein, sulphatase and dextran-coated charcoal were purchased from Sigma (St. Louis, MO, USA). Cell counting kit-8 (CCK-8) was obtained from Dojindo Laboratory (Kumamoto, Japan). 
BPA and DEHP were purchased from Shanghai Chemical Reagents Company (Shanghai, China). Akt and phospho-Akt (Ser473; p-Akt) antibodies were obtained from Cell Signaling Technology (Beverly, MA, USA). $\mathrm{E}_{2}$, BPA, DEHP and genistein were dissolved in Dimethyl Sulfoxide (DMSO), and then diluted with phenol red-free RPMI-1640 medium containing charcoal-dextran-stripped FBS (cd-FBS) to final concentration for culturing at $1 \mathrm{ng} / \mathrm{ml} \mathrm{E}_{2}, 2 \mu \mathrm{g} / \mathrm{ml} \mathrm{BPA}, 100 \mu \mathrm{M} / 1 \mathrm{DEHP}$ and $12.5 \mu \mathrm{M} / 1$ genistein, respectively. The final solvent concentration in the culture did not exceed $0.1 \%$.

Cell culture and treatment. SK-N-SH cells were cultured in 75- $\mathrm{cm}^{2}$ flasks with RPMI-1640 medium supplemented with $0.1 \mathrm{M}$ L-glutamine, $10 \%$ (v/v) FBS, $100 \mathrm{U} / \mathrm{ml}$ of penicillin, $100 \mu \mathrm{g} / \mathrm{ml}$ of streptomycin at $37^{\circ} \mathrm{C}$ with $5 \% \mathrm{CO}_{2}$ in a fully humidified incubator. Prior to treatments, cells were starved in phenol red-free RPMI-1640 medium without FBS for $24 \mathrm{~h}$. The study was approved by the ethics committee of Children's Hospital, Fudan University.

CCK- 8 assay. SK-N-SH cells were seeded into 96-well flatbottomed microtiter plates at a density of $10^{5} / \mathrm{ml}$ and the final volume in each well was $100 \mu \mathrm{l}$. After being starved, cells were then treated with $1 \mathrm{ng} / \mathrm{ml} \mathrm{E}_{2}, 2 \mu \mathrm{g} / \mathrm{ml} \mathrm{BPA}$, or $100 \mu \mathrm{M} / 1$ DEHP with or without $12.5 \mu \mathrm{M} / 1$ genistein. The number of viable cells was detected with CCK-8 assay as described previously, at $0,24,48$ and $72 \mathrm{~h}(4,5)$. The treatment wells were in quadruplicates and the whole experiment was repeated independently three times.

Flow cytometry. Cells were cultured into 6-well plates at a density of $3 \times 10^{5} / \mathrm{ml}$, and then treated as described above. After $72 \mathrm{~h}$ incubation, $10^{6}$ cells were fixed with $1 \mathrm{ml} 70 \%$ ethanol at $4^{\circ} \mathrm{C}$ for $30 \mathrm{~min}$ and then stained with staining solution $(2 \mathrm{mg} / \mathrm{ml}$ propidium iodide and $10 \mathrm{mg} / \mathrm{ml} \mathrm{RNase}$ in PBS) at $37^{\circ} \mathrm{C}$ for $30 \mathrm{~min}$. Stained cells were analyzed for fluorescence intensity with a fluorescence-activated cell sorter (Becton Dickinson, San Jose, CA, USA) equipped with an argon laser emitting at $488 \mathrm{~nm}$, using the CellQuest software (Becton Dickinson). A minimum of 10,000 events were acquired for each determination. The percentages of cells in $\mathrm{G}_{2} / \mathrm{M}$ phases were calculated by the ModFit program (Becton Dickinson).

Western blot analysis. Neuroblastoma cells were plated in $100-\mathrm{mm}$ dishes and subsequently treated as described above for $72 \mathrm{~h}$. Then cells were collected in RIPA buffer $(50 \mathrm{mmol} / \mathrm{l}$ Tris- $\mathrm{HCl}, \mathrm{pH} 7.5,150 \mathrm{mmol} / 1 \mathrm{NaCl}, 0.5 \%$ deoxycholate, $0.1 \%$ sodium dodecyl sulfate) on ice for $15 \mathrm{~min}$. Protein concentrations were determined by the Bradford method and protein extracts (50 $\mu \mathrm{g} /$ lane) were loaded on an $8 \%$ SDS-polyacrylamide gels. After gel separation, proteins were transferred to a nitrocellulose membrane. The membrane was blocked with 5\% skimmed milk, then separately incubated with anti-Akt antibody (1:1000 dilution), anti-p-Akt antibody (1:200 dilution). Incubation with anti- $\beta$-actin antibody (1:5000 dilution) was performed together as an internal control. The membranes were visualized with an enhanced chemiluminescence system according to the manufacturer's instructions. The bands on the western blot films were scanned by VersaDoc Image Analysis System (Bio-Rad, Hercules, CA, USA), and
Table I. $\mathrm{G}_{2} / \mathrm{M}$ phase analysis of SK-N-SH cells at $72 \mathrm{~h}$.

\begin{tabular}{lclc}
\hline Groups & $\mathrm{G}_{2} / \mathrm{M}(\%)$ & \multicolumn{1}{c}{ Groups } & $\mathrm{G}_{2} / \mathrm{M}(\%)$ \\
\hline Control & $9.15 \pm 1.08$ & Genistein & $16.58 \pm 2.71^{\mathrm{c}}$ \\
$\mathrm{E}_{2}$ & $11.70 \pm 1.14^{\mathrm{a}}$ & E2+genistein & $15.56 \pm 0.58^{\mathrm{b}}$ \\
BPA & $11.94 \pm 0.06^{\mathrm{a}}$ & BPA+genistein & $17.76 \pm 1.45^{\mathrm{c}}$ \\
DEHP & $11.64 \pm 0.39^{\mathrm{a}}$ & DEHP+genistein & $15.99 \pm 0.98^{\mathrm{c}}$ \\
\hline
\end{tabular}

Compared with control group, ${ }^{\text {a }}<0.05$; Compared with groups without genistein, ${ }^{b} \mathrm{P}<0.01$; ${ }^{\mathrm{c}} \mathrm{P}<0.001$. BPA, bisphenol A; DEHP, Di-2-ethylhexyl phthalate.

analyzed with the QualityOne Image Analysis software (Bio-Rad).

Statistical analysis. All results were analyzed using SPSS 11.5 software (SPSS Inc., Chicago, IL, USA). Data were expressed as mean \pm standard error of mean (SEM) of separate experiments $(n \geq 3)$ and compared by one-way analysis of variance (ANOVA). The difference between two treatments was considered significant at $\mathrm{P}<0.05$.

\section{Results}

Genistein suppressed SK-N-SH cell proliferation induced by $E_{2}, B P A$ and DEHP. The effect of genistein on the proliferation of neuroblastoma cells was assessed using CCK-8 proliferation assay. Time- and dose-dependent experiments showed that genistein inhibited the SK-N-SH cell growth in a dose-dependent manner (data not shown). After $24 \mathrm{~h}$ treatment, absorbance values (AVs) among all the groups showed no significant difference. Then at $48 \mathrm{~h}$, the AVs of the $\mathrm{E}_{2}, \mathrm{BPA}$ and DEHP groups $(0.72 \pm 0.06,0.75 \pm 0.02,0.74 \pm 0.05$, respectively) were significantly higher than those of the control group $(0.56 \pm 0.03, \mathrm{P}<0.001$; Fig. 1). However, there was not a similar increase of $\mathrm{AV}$ in groups treated with $\mathrm{E}_{2}$, BPA or DEHP with additional genistein treatment. The AVs in these groups were not significantly higher than those in the control group ( $\mathrm{P}>0.05)$, but were evidently lower than those in the groups treated with $\mathrm{E}_{2}$, BPA and DEHP alone $(\mathrm{P}<0.001$; Fig. 1). At $72 \mathrm{~h}$, a similar phenomenon was noted (Fig. 1).

Genistein arrested $S K-N-S H$ cells at $G_{2} / M$ phase of cell cycle. After $72 \mathrm{~h}$ treatment, flow cytometric analysis was also applied to investigate whether the effect of genistein inhibition against neuroblastoma cell proliferation occurred in a cell cycle-dependent manner. When cells were treated with additional genistein, the percentage of cells in the $G_{2} / M$ phase significantly increased. Cells were arrested at the $G_{2} / M$ phase of the cell cycle $\left(\mathrm{P}>0.05\right.$ vs. the control group; $\mathrm{P}<0.01$ vs. $\mathrm{E}_{2}$, BPA or DEHP groups; Table I).

Genistein modulated $p$-Akt (Ser473) protein expression. Akt and p-Akt expression levels were further detected by western blot analysis to determine the principal signaling mechanism of genistein inhibiting SK-N-SH cell growth at $72 \mathrm{~h}$ after drug treatments. The expression of p-Akt was abundant when 


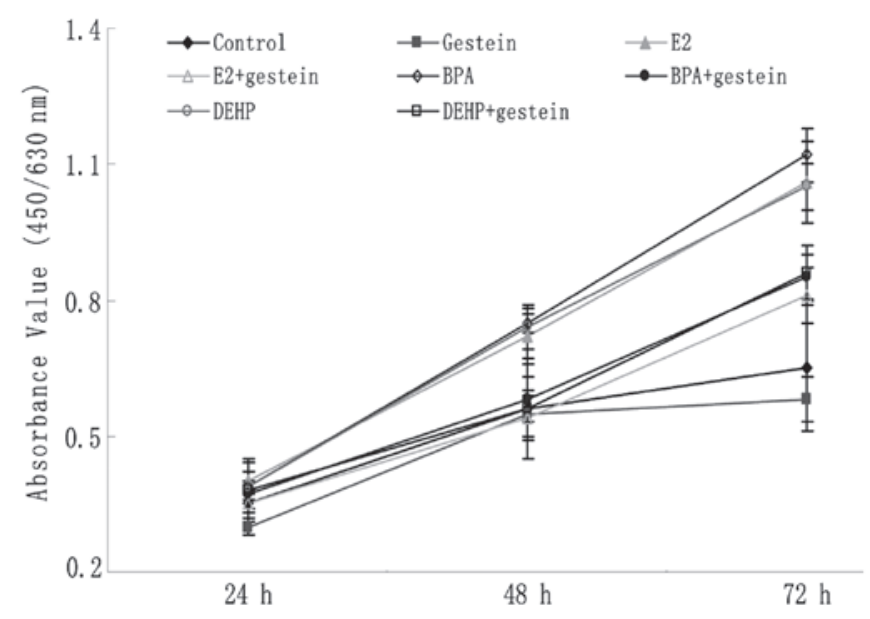

Figure 1. Growth curves of SK-N-SH cells from 0 to $72 \mathrm{~h}$ after drug treatment. SK-N-SH cells were treated with $1 \mathrm{ng} / \mathrm{ml} 17 \beta$-estradiol $\left(\mathrm{E}_{2}\right), 2 \mu \mathrm{g} / \mathrm{ml}$ bisphenol A (BPA) or $100 \mu \mathrm{M} / 1$ di-2-ethylhexl phthalate (DEHP), with or without $12.5 \mu \mathrm{M} / 1$ genistein. BPA, DEHP and $\mathrm{E}_{2}$ significantly promoted the proliferation of SK-N-SH cells in vitro at 48 and $72 \mathrm{~h}$, while genistein inhibited the proliferation effects.

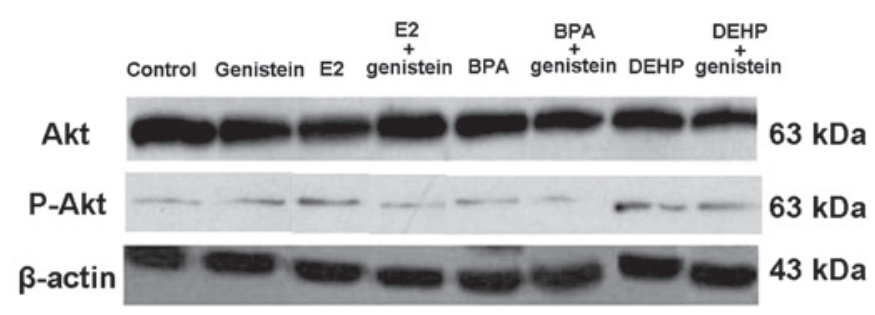

Figure 2. The expression of Akt and p-Akt in SK-N-SH cells detected by western blot analysis. At $72 \mathrm{~h}$, the expression of Akt was abundant in every group. p-Akt was abundant in the E2, BPA and DEHP group, while weak in the control and genistein group. BPA, bisphenol A; DEHP, Di-2-ethylhexyl phthalate.

treated with $\mathrm{E}_{2}$, BPA or DEHP only (Fig. 2). By contrast, there was no increase in the expression of p-Akt protein in the genistein-treated groups (Fig. 2). Akt protein expression had no significant change in any of the groups.

\section{Discussion}

During the last decade, soy isoflavones mainly derived from soybean received much attention as dietary components having inhibitory effects on cancers. The lower risk of breast and prostate cancers in Asians, who consume 20-50 times more soy than Americans, has raised the question whether compounds in the soy diet act as a natural chemopreventive agent. Indeed, a cross-national study involving 59 countries identified that soy products have a highly significant effect against the development of prostate cancer (12). Elevated levels of soy isoflavones in the micromolar range have been detected in the serum, urine, prostatic fluid and prostate tissue in vegetarians and Asian men who consume a soy-rich diet and have low risk of prostate cancer (13). In contrast, serum concentration of genistein in Americans and Europeans is in the nanomolar range (13).
Soy isoflavones include genistein, daidzein and glycitein. However, genistein is the principal isoflavone in soy that has been demonstrated to be responsible for reducing the incidence of hormone-related cancers. In laboratory in vitro experiments, genistein has been found to inhibit the growth of various cancer cell lines including prostate and breast cancer cells (14). Moreover, the evidence from in vitro studies has demonstrated that genistein exerts its inhibitory effects on the development of cancers, cancer cell growth, cancer progression, cancer cell invasion, metastasis and angiogenesis (14).

The direct anti-tumor activity, action mechanisms and therapeutic potential of genistein on neuroblastoma cells have been investigated $(8,15)$. We have previously reported that environmental endocrine disruptor BPA promoted the proliferation of SK-N-SH cells in vitro and in vivo $(4,5)$. However, the effects of genistein on the growth-promoted action of BPA and DEHP on human neuroblastoma cells and its action mechanisms remain poorly understood. In the current study, we hypothesized that genistein may also inhibit the human neuroblastoma cell proliferation induced by EED and estrodiol in vitro.

Our results showed that the proliferation of neuroblastoma cells is enhanced by estrogen and certain environmental estrogen-like contaminants. When genistein was used in combination with $\mathrm{E}_{2}$, BPA or DEHP, cell growth was inhibited effectively. This is in agreement with other studies involving several types of cells (16-18). The present results demonstrated that genistein suppressed SK-N-SH cell proliferation induced by BPA and DEHP.

In addition, genistein prevented the SK-N-SH cells from entering the $\mathrm{G}_{2} / \mathrm{M}$ phase during the cell cycle, suggesting that the observed growth-inhibitory effect of genistein was mediated through modulation of cell cycle progression in SK-N-SH cells. Our results are in line with others which showed that genistein exerts its anti-tumor effects by arresting SK-N-SH cells in $\mathrm{G}_{2} / \mathrm{M}$ phase and inhibiting cancer cell death (19).

The phosphatidylinositol-3 kinase/Akt (PI3K/Akt) signaling pathway plays a critical role in cell survival and apoptosis. Inhibition of the PI3K/Akt pathway has been considered as a therapeutic target for cancer where PI3K/Akt activation is a causative factor. It has also been reported that genistein inhibits the activation of the Akt signaling pathway in prostate and breast cancer cell lines $(20,21)$. In our study, the expression of p-Akt was abundant in the $\mathrm{E}_{2}$, BPA and DEHP groups, but genistein caused a decrease in active p-Akt levels.

In summary, BPA and DEHP have growth-promoting effects on human neuroblastoma SK-N-SH cells in vitro, which can be inhibited by genistein. Genistein significantly inhibited the growth of neuroblastoma cells through modulation of cell cycle progression and the PI3K/Akt pathway. The results of our study provide the experimental basis for the application of genistein in additional preventive or therapeutic strategies in neuroblastoma.

\section{Acknowledgements}

These results were presented at the 42nd Annual Meeting of the Pacific Association of Pediatric Surgeons, May 9 to May 14, 2009, Hongkong, China. We thank the Institute of Biochemistry and Cell Biology, Shanghai Institutes for 
Biological Sciences, and the Chinese Academy of Sciences for their help with the flow cytometric analysis. This study was supported by the National Natural Science Foundation Commission (30801198/C1611) and the Doctoral Fund of Ministry of Education of China.

\section{References}

1. van Noesel MM and Versteeg R: Pediatric neuroblastomas: genetic and epigenetic 'danse macabre'. Gene 325: 1-15, 2004.

2. Izbicka $\mathrm{E}$ and Izbicki T: Therapeutic strategies for the treatment of neuroblastoma. Curr Opin Investig Drugs 6: 1200-1214, 2005.

3. DuBois SG, Kalika Y, Lukens JN, et al: Metastatic sites in stage IV and IVS neuroblastoma correlate with age, tumor biology, and survival. Journal of pediatric hematology/oncology 21: 181-189, 1999.

4. Zheng J, Xiao X, Liu J, Zheng S, Yin Q and Yu Y: Growthpromoting effect of environmental endocrine disruptors on human neuroblastoma SK-N-SH cells. Environ Toxicol Pharmacol 24: 189-193, 2007.

5. Zhu H, Xiao X, Zheng J, Zheng S, Dong K and Yu Y: Growthpromoting effect of bisphenol A on neuroblastoma in vitro and in vivo. J Pediatr Surg 44: 672-680, 2009.

6. De Roos AJ, Olshan AF, Teschke K, et al: Parental occupational exposures to chemicals and incidence of neuroblastoma in offspring. Am J Epidemiol 154: 106-114, 2001.

7. Formica JV and Regelson W: Review of the biology of Quercetin and related bioflavonoids. Food Chem Toxicol 33: 1061-1080, 1995.

8. Ismail IA, Kang KS, Lee HA, Kim JW and Sohn YK: Genisteininduced neuronal apoptosis and $\mathrm{G} 2 / \mathrm{M}$ cell cycle arrest is associated with MDC1 up-regulation and PLK1 down-regulation. Eur J Pharmacol 575: 12-20,2007.

9. Park OJ and Surh YJ: Chemopreventive potential of epigallocatechin gallate and genistein: evidence from epidemiological and laboratory studies. Toxicol Lett 150: 43-56, 2004.

10. Magee PJ and Rowland IR: Phyto-oestrogens, their mechanism of action: current evidence for a role in breast and prostate cancer. Br J Nutr 91: 513-531, 2004.
11. Sarkar FH and Li Y: Soy isoflavones and cancer prevention. Cancer investigation 21: 744-757, 2003.

12. Hebert JR, Hurley TG, Olendzki BC, Teas J, Ma Y and Hampl JS: Nutritional and socioeconomic factors in relation to prostate cancer mortality: a cross-national study. J Natl Cancer Inst 90: 1637-1647, 1998.

13. Rannikko A, Petas A, Rannikko S and Adlercreutz H: Plasma and prostate phytoestrogen concentrations in prostate cancer patients after oral phytoestogen supplementation. The Prostate 66: 82-87, 2006.

14. Li Y and Sarkar FH: Inhibition of nuclear factor kappaB activation in PC3 cells by genistein is mediated via Akt signaling pathway. Clin Cancer Res 8: 2369-2377, 2002.

15. Lo FH, Mak NK and Leung KN: Studies on the anti-tumor activities of the soy isoflavone daidzein on murine neuroblastoma cells. Biomed Pharmacother 61: 591-595, 2007.

16. Linford NJ, Yang Y, Cook DG and Dorsa DM: Neuronal apoptosis resulting from high doses of the isoflavone genistein: role for calcium and p42/44 mitogen-activated protein kinase. J Pharmacol Exp Ther 299: 67-75, 2001.

17. Hewitt AL and Singletary KW: Soy extract inhibits mammary adenocarcinoma growth in a syngeneic mouse model. Cancer Lett 192: 133-143, 2003.

18. Chang KL, Kung ML, Chow NH and Su SJ: Genistein arrests hepatoma cells at G2/M phase: involvement of ATM activation and upregulation of p21waf1/cip1 and Wee1. Biochem Pharmacol 67: 717-726, 2004.

19. Sarkar FH, Adsule S, Padhye S, Kulkarni S and Li Y: The role of genistein and synthetic derivatives of isoflavone in cancer prevention and therapy. Mini reviews in medicinal chemistry 6: 401-407, 2006.

20. Gong L,Li Y, Nedeljkovic-Kurepa A and Sarkar FH: Inactivation of NF-kappaB by genistein is mediated via Akt signaling pathway in breast cancer cells. Oncogene 22: 4702-4709, 2003.

21. Park SS, Kim YN, Jeon YK, et al: Genistein-induced apoptosis via Akt signaling pathway in anaplastic large-cell lymphoma. Cancer chemother Pharmacol 56: 271-278, 2005. 